MAŁGORZATA MIREK* - NOWY SĄCZ

\title{
DZIEDZICTWO KULTUROWE ŚWIETTEJ KINGI. ZE ZBIORÓW BIBLIOTEKI SIÓSTR KLARYSEK W STARYM SĄCZU
}

W dniach od 14 czerwca do 25 sierpnia 2013 r. w Galerii „Dawna Synagoga”, jednym z oddziałów Muzeum Okręgowego w Nowym Sączu, prezentowana była wystawa Dziedzictwo kulturowe świętej Kingi ${ }^{1}$. To kolejna już, zorganizowana przez muzeum nowosądeckie w ostatnich kilkunastu latach, ekspozycja z cyklu Skarby klasztorów i kościołów ziemi sądeckiej, przybliżająca ich historię i kulturę. Kuratorami wystawy były Edyta Ross-Pazdyk i Barbara Szafran, pracownicy muzeum. Wystawie towarzyszył katalog Dziedzictwo kulturowe świętej Kingi².

Założycielką klasztoru klarysek w Starym Sączu była Kinga (Kunegunda), córka króla Węgier Beli IV z dynastii Arpadów i Marii Laskaris, pochodzącej z cesarskiej rodziny bizantyjskiej ${ }^{3}$. Urodziła się 5 marca 1234 r. w Ostrzyhomiu. W 1239 r. została wysłana do Polski i przyrzeczona dwunastoletniemu wówczas księciu sandomierskiemu Bolesławowi Wstydliwemu. Do zawarcia związku małżeńskiego doszło dopiero w 1246 r. Na dworach królewskim w Budzie i książęcym w Sandomierzu otrzymała staranne wykształcenie. Tam też ukształtowała swoją religijność. W Polsce nad wychowaniem Kingi czuwała matka męża księżna Grzymisława oraz jego siostra księżna Salomea, pierwsza klaryska na ziemiach

* Małgorzata Mirek - dr historii; wykładowca w Państwowej Wyższej Szkole Zawodowej w Nowym Sączu, e-mail: gosiam_1973@o2.pl

${ }^{1}$ Projekt zrealizowany został z dotacji celowej Województwa Małopolskiego i dofinansowany ze środków Ministerstwa Kultury i Dziedzictwa Narodowego oraz objęty przez te podmioty honorowym patronatem. Ponadto honorowymi patronami byli: bp Andrzej Jeż - Ordynariusz Diecezji Tarnowskiej oraz o. Marco Tasca OFMConv. - Minister Generalny Zakonu Braci Mniejszych Konwentualnych.

${ }^{2}$ Dziedzictwo kulturowe świętej Kingi. Katalog wystawy zrealizowanej ze zbiorów klasztoru Sióstr Klarysek w Starym Saczu, red. nauk. R. Ślusarek, Nowy Sącz 2013.

${ }^{3}$ Zob. Z. Budkowa, Kunegunda, w: Polski Stownik Biograficzny, t. 16, Wrocław 1971, s. 186189; M.H. Witkowska, Kinga, Kunegunda, w: Hagiografia polska. Stownik bio-bibliograficzny, t. 1, red. R. Gustaw, Poznań 1971, s. 757-772; K. Szwarga, Błogostawiona Kinga, Warszawa 1989; J. Misiurek, Kinga, Kunegunda, w: Encyklopedia katolicka, t. 8, red. B. Migut, Lublin 2000, kol. 1450-1451. 
polskich, założycielka klasztoru w Zawichoście. Małżeństwo Kingi i Bolesława Wstydliwego przypadło na trudny okres w dziejach Polski. Podobnie jak inne kraje Europy, ze wschodu nękały ją najazdy Tatarów, a z północy Jaćwingów. W 1257 r. Kinga, na mocy przywileju, otrzymała od męża ziemię sądecką, jako zabezpieczenie wniesionego przez nią posagu, który książę przeznaczył na potrzeby związane z odbudową ziem zniszczonych przez Tatarów w $1241 \mathrm{r}$. i w czasie późniejszych najazdów ${ }^{4}$. Po śmierci Bolesława Wstydliwego w 1279 r., Kinga zrzekła się władzy książęcej i przeniosła do Starego Sącza, gdzie 6 lipca 1280 r. ufundowała klasztor klarysek ${ }^{5}$. Dnia 31 października tego roku książę krakowski i sandomierski Leszek Czarny potwierdził jej posiadanie ziemi sądeckiej jako uposażenia wdowiego ${ }^{6}$. Dziewięć lat później, w 1289 r., Kinga złożyła śluby zakonne. Klasztor otrzymał najhojniejsze uposażenie spośród żeńskich fundacji powstałych w XIII wieku w Polsce. Wpływ na to miały zarówno reguła zakonu, zatwierdzona przez papieża Urbana IV w 1263 r., zezwalająca na posiadanie wspólnej własności przez klasztor, jak i osoba fundatorki. Kinga przekazała klaryskom miasto Stary Sącz z wszystkimi dochodami, w tym także z cłem z miejscowej komory, oraz 28 okolicznych wsi. Dnia 5 lipca 1283 r. papież Marcin IV potwierdził bullą ofiarowaną przez nią darowiznę ${ }^{7}$. Opiekę duchową nad klaryskami sprawowali od początku franciszkanie sprowadzeni do Starego Sącza przez Kingę. Od końca XVI wieku ich rolę przejęli księża świeccy. Kinga zmarła w opinii świętości 24 lipca 1292 r. Pochowana została pod posadzką kaplicy klasztornej. Siostry od jej śmierci czyniły starania o uznanie fundatorki za świętą. Jednak dopiero 11 czerwca 1690 r. papież Aleksander VIII zatwierdził kult Kingi i włączył ją w poczet błogosławionych. Dnia 16 czerwca 1999 r. papież Jan Paweł II kanonizował ją na starosądeckich błoniach podczas swojej siódmej pielgrzymki do Polski.

Klasztor klarysek w Starym Sączu przetrwał do dziś pomimo wielu niebezpieczeństw i burz dziejowych. Siostry przez wieki odgrywały ważną rolę w dziejach Sądecczyzny, tworząc jej dziedzictwo duchowe, kulturowe i materialne. Konwent cieszył się wsparciem i opieką polskich królów i królowych m.in. Władysława Łokietka i jego żony Jadwigi, Kazimierza Wielkiego i jego siostry Elżbiety Łokietkówny, Władysława Jagiełły i jego czwartej żony Zofii Holszańskiej oraz Zygmunta Starego. Ksienie i prokuratorzy troszczyli się o nadane przez Kingę dobra. Klasztor czerpał dochody w postaci czynszów, dziesięcin, płodów rolnych z miasta i wsi. Prowadził także akcję lokacyjną i dbał o to, aby majątek nie był zmniejszany. Przełomowym okresem w dziejach klasztoru był koniec XVI wieku, kiedy to w wyniku zmian zachodzących w Kościele po Soborze Trydenckim i odnowie życia religijnego władzę nad klasztorami żeńskimi, w tym także starosądeckim, przejęli biskupi. Pierwszym reformatorem życia klauzurowego był biskup krakowski, kardynał Jerzy Radziwiłł, który wizytował konwent trzy razy w latach 1596-1599. Z ostatniego jego pobytu zachował się obszerny dekret re-

${ }^{4}$ Kodeks Dyplomatyczny Małopolski (dalej: KDM), wydał i przypisami objaśnił F. Piekosiński, t. 2, Kraków 1886, nr CCCCLII, s. 106-108.

${ }^{5} \mathrm{KDM}$, t. 2, nr CCCCLXXXVII, s. 145-146.

${ }^{6} \mathrm{KDM}$, t. 2, nr CCCCXC, s. 149-150.

${ }^{7} \mathrm{KDM}$, t. 2, nr CCCCXCVI, s. 153-154. 
formacyjny przechowywany do dzisiaj w archiwum klasztornym ${ }^{8}$. Radziwiłł zarządził przebudowę klasztoru i niewielkie naprawy w kościele Św. Trójcy. Druga połowa XVIII wieku była jednym z najtrudniejszych okresów w historii klasztoru. Kontrybucje wojenne i przemarsze wojsk, pożary, w tym najtragiczniejszy w roku 1764, w czasie którego zniszczone zostały dachy klasztoru i kościoła, miały wpływ na życie klarysek i stan gospodarki klasztornej. W czasie rozbiorów Polski, mimo formalnej kasaty, ogłoszonej w Starym Sączu 11 lutego 1782 r., zezwolono klaryskom na pozostanie w klasztorze do śmierci. Jednocześnie utracił on prawo do przyjmowania kandydatek do nowicjatu. W tym też roku, konwent został pozbawiony własności i dóbr ziemskich, a także wszelkich kosztowności, w tym relikwii fundatorki, oraz archiwaliów i księgozbioru. Dopiero zmiana nastawienia władz austriackich wobec Kościoła na początku XIX wieku pozwoliła na przywrócenie nowicjatu i tym samym na przetrwanie wspólnoty zakonnej. Dnia 15 marca 1811 r. cesarz Franciszek I wydał dekret, w którym zezwolił na otwarcie nowicjatu pod warunkiem prowadzenia przez klaryski szkoły dla dziewcząt. Dopiero dziesięć lat później, w 1821 r., siostry otworzyły szkołę pod nazwą ,Mädchen Hauptschule an der Erziehungs Anstalt des Sancta Clara Nonnen Klosters zu Alt Sandez". Czteroklasowa szkoła, z językiem niemieckim jako wykładowym, w roku 1864 została przekształcona na pięcioklasową „CesarskoKrólewską Wyższą Szkołę Panieńską" z językiem polskim wykładowym. Pod koniec XIX wieku istniała przy klasztorze siedmioklasowa Szkoła Ludowa, a w latach 1904-1908 Prywatne Seminarium Nauczycielskie Żeńskie. W 1912 r. w budynku szkoły klasztornej zaczęła działać Szkoła Publiczna Miejska im. Królowej Jadwigi, przeniesiona następnie w pobliże kościoła parafialnego św. Elżbiety. Pierwszą wojnę światową klaryski spędziły w klasztorze, przyjmując pod opiekę benedyktynki ze Staniątek. Po wojnie otworzono w 1921 r. siedmioklasową Publiczną Szkołę Powszechną Żeńską im. św. Kingi, a rok później Prywatne Seminarium Nauczycielskie Żeńskie. Klaryski, chcąc powrócić do klauzurowego charakteru swojej wspólnoty i kontemplacyjnego charyzmatu zakonu, przekazały w 1938 r. prawo prowadzenia szkoły publicznej, wówczas już Prywatnego Gimnazjum Żeńskiego im. św. Kingi, Zarządowi Miasta Starego Sącza9.

Celem omawianej wystawy była prezentacja szerszej publiczności części spuścizny artystycznej klasztoru klarysek w Starym Sączu. Większość prezentowanych eksponatów po raz pierwszy od wieków, dzięki zaufaniu i dużej życzliwości ówczesnej matki ksieni Teresy Anny Izworskiej OSC oraz siostry Salomei Stompel OSC i całego konwentu klarysek, opuściła mury klasztorne. Wśród nich znalazły się m.in. pamiątki według tradycji klasztornej należące do św. Kingi, pochodzące $\mathrm{z}$ drugiej połowy XIII wieku (medalion owalny z antyczną gemmą w formie profilowanej głowy na awersie i wizerunkiem Chrystusa Ukrzyżowanego na rewersie, łyżeczka ze złoconego srebra $\mathrm{z}$ agatowym lub jaspisowym wnę-

${ }^{8}$ Archiwum SS. Klarysek w Starym Sączu (dalej: AKlar. St. Sącz), sygn. Rf/a-1, Reformatia od Jego Xancti M. Xiędza Jerzego Cardinała Radziwiłła Biskupa Krakowskiego, Pannom Klasztoru Starosądeckiego zostawiona Roku 1599 dnia X sierpnia.

${ }^{9}$ O.M. Przybyłowicz, Zarys dziejów klasztoru SS. Klarysek w Starym Saczu, w: Dziedzictwo kulturowe świętej Kingi, s. 5-6. 
trzem czerpaka, kubek kryształowy w srebrnej neorokokowej oprawie, relikwiarz ampułkowy, trzon kościany noża i pierścień z intaglio wykonanym z ametystu, przedstawiającym dwie witające się postacie ukazane z profilu), a także cenne w zbiorach dzieła rzemiosła artystycznego, zabytki piśmiennictwa oraz wysokiej klasy artystycznej rzeźba i malarstwo z okresu od XV do XVIII wieku.

Na przełomie XII i XIII wieku w Europie miały miejsce znaczące zmiany zachodzące na płaszczyźnie życia publicznego i kościelnego. Jednym z przejawów tych przemian były powstające w tym czasie nowe formy życia zakonnego. Odgrywały one ważną rolę nie tylko w Kościele, ale również w sferze publicznej i kulturowej. W kontekście tej ostatniej nowe klasztory, katedry i większe kościoły były miejscem powstawania nowych kompozycji i utrwalania się już istniejących, tworząc zbiory liturgiczne ${ }^{10}$. W 1278 r. papież Mikołaj III, w celu uporządkowania liturgii wprowadził we wszystkich kościołach Rzymu, w miejsce dotychczas stosowanych ksiąg, kodeksy franciszkańskie. Ta unifikacja zaczęła rozszerzać się w całej Europie. W XIII wieku tradycja całej rodziny franciszkańskiej w odniesieniu do zasad tworzenia kodeksów charakteryzowała się ściśle przestrzeganymi klauzulami skryptorskimi uchwalonymi na kolejnych kapitułach zakonu. Zapisywane one były na pierwszych kartach kodeksów i rozpoczynały się od słów Ista rubrica. Charakterystyczną notą franciszkańskich kodeksów stał się odtąd zwrot secundum ordinem Curiae Romanae, którym określano zasady leżące u podstaw komponowania rękopisów ${ }^{11}$. Skryptorska tradycja franciszkańska zostawiła po sobie niezwykle bogatą spuściznę, a szczególne miejsce w tym zbiorze zajmują kodeksy klarysek polskich, w tym także klarysek starosądeckich. Posiadane przez nie manuskrypty są reprezentatywnym i jednym z najstarszych przykładów ksiąg napisanych już po reformie wprowadzonej przez papieża Mikołaja III.

Klaryski w Starym Sączu prowadziły i nadal prowadzą bardzo bogate życie duchowe zgodne $\mathrm{z}$ ich regułą zobowiązującą siostry do codziennego odmawiania i śpiewania modlitw liturgicznych oraz uczestniczenia we mszy św. Jak pisze Henryk Cempura:

Od początku istnienia tego klasztoru, prawdopodobnie w związku z tradycjami franciszkańskimi, istniały powiązania liturgii i całej obrzędowości zakonnej z muzyką i śpiewem. Biografowie łączą ten fakt z osobą św. Kingi, która pierwsza w historii polskich klarysek miała zapoczątkować śpiewanie zakonnic w czasie mszy św. oraz nieszporów ${ }^{12}$.

Świadczą o tym zachowane do dzisiaj cenne w zbiorach biblioteki klasztornej m.in. graduały z końca XIII i pierwszej połowy XIV wieku, antyfonarz z drugiej połowy XIII wieku, psałterz z przełomu XIII i XIV wieku, a także rozmyślania duchowe, stanowiące przewodnik życia wewnętrznego dla nowicjuszek i sióstr po ślubach zakonnych, czyli profesji, oraz żywoty świętych i księgi liturgiczne.

$\mathrm{Na}$ wystawie prezentowane były trzy graduały. Pierwszy z nich Graduale

${ }^{10} \mathrm{~J}$. Sok, Wptyw klarysek starosądeckich na rozwój kultury liturgiczno-muzycznej na przełomie XIII i XIV wieku, ,Studia Redemptorystowskie”, 6 (2008) s. 9; S. Garnczarski, Kultura muzyczna w klasztorze klarysek w Starym Saczu, ,Tarnowskie Studia Teologiczne”, 33 (2014) nr 2, s. 127.

${ }^{11}$ Sok, Wplyw klarysek, s. 9-10.

${ }^{12}$ H. Cempura, Kultura muzyczna klasztoru PP. Klarysek w Starym Saczu w latach 1700-1782, Tarnów 2009, s. 17. 
Romanum Franciscanum ${ }^{13}$ zwany „dużym”, datowany jest na drugą połowę XIII wieku. Manuskrypt ten sporządzony został na pergaminie północnym (charta theutonica), który w odróżnieniu od pergaminu południowego (charta italica) był nieco grubszy i obustronnie wyprawiony, co pozwalało kopiście na zapisywanie treści na dwóch stronach. Pergamin północny używany był do redagowania rękopisów liturgicznych m.in. w północnej Francji, Niemczech, Polsce i na Węgrzech ${ }^{14}$. Kodeks zawiera 192 karty pergaminowe i 8 kart papierowych, dołączonych w XIV wieku, rozmieszczonych w różnych miejscach rękopisu. Karty nie posiadały paginacji naniesionej przez kopistę, sporządzono ją dopiero 20 sierpnia 1963 r. Paginacja ręczna wykonana została za pomocą liczb nieparzystych na stronach recto 1-383, bez uwzględnienia dodatków papierowych. Tekst śpiewów pisany był teksturą gotycką z elementami zaokrągleń romańskich czarnym atramentem, w języku łacińskim. Pod względem notacji muzycznej rękopis prezentuje charakterystyczny dla kodeksów franciszkańskich typ notacji kwadratowej nota quadrata na czterech czerwonych liniach. Wyjątek stanowi hymn Dilectus Deo et hominibus na stronie 6, zapisany na pięciu czerwonych liniach, umieszczony na siedmiu systemach. Noty rubrycystyczne wykonane zostały czerwonym i czarnym atramentem. Na jednej stronie znajduje się po dziewięć systemów złożonych z tekstu i melodii. Niekiedy duża ilość not rubrycystycznych sprawia, że na kilku stronach zapisano mniej systemów. Mniejsze inicjały są w kolorach czarnym i czerwonym. Występują w nich nieskomplikowane dekoracje rysunkowe przedstawiające $m$.in. twarze i postacie zakonnic, syreny, ptaki i smoki. Większe inicjały wykonane zostały piórem, brunatnym i czarnym atramentem oraz czerwonym i niebieskim pigmentem, w różnych odcieniach. Treść rękopisu stanowią części zmienne śpiewów mszalnych, czyli introity, graduały, wiersze allelujatyczne, traktusy, offertoria i communiones oraz części stałe mszy św., a więc Kyrie, Gloria, Sanctus i Agnus Dei. Jest to graduał kompletny, zawierający zestaw śpiewów De tempore i De sanctis oraz Commune sanctorum, Ordinarium missae, a także formularze mszy św. wotywnych. W manuskrypcie znalazły się też formularze mszalne na najstarsze uroczystości maryjne: Oczyszczenie NMP, Zwiastowanie, Wniebowzięcie i Narodzenie. Ponadto na stronach 215-218 znajduje się formularz mszy św. o Najświętszej Trójcy, natomiast brakuje formularza na Boże Ciało. Kalendarz świąt rozpoczyna się wigilią św. Andrzeja, a kończy uroczystością św. Klemensa. Szczególnie podkreśleni zostali święci franciszkańscy: św. Franciszek i św. Antoni. W litanii z Wielkiej Soboty dopisano późniejszą ręką imiona świętych: Stanisława, Mikołaja, Ludwika, Dominika, Anny, Klary, Elżbiety, Jadwigi, Katarzyny i Małgorzaty. Na stronach 373-383 mieszczą się dodatki późniejsze, pochodzące prawdopodobnie z pierwszej połowy XIV wieku. Ten fragment rękopisu zawiera na stronach 378-380 dwugłosową, tropową lekcję na Boże Narodzenie Jube domne benedicere. Oprawę stanowi deska obciągnięta brązową skórą. Oprawa na grzbiecie jest zniszczona. Skóra na przedniej okładzinie została odcięta. Zachowały się fragmenty po dwóch metalowych klauzurkach,

\footnotetext{
${ }^{13}$ Biblioteka SS. Klarysek w Starym Sączu (dalej: BKlar. St. Sącz), sygn. Muz. 1.

${ }^{14}$ Encyklopedia wiedzy o książe, Wrocław 1971, p. 1825.
} 
służących do zamykania księgi oraz jeden metalowy guz na wierzchnim licu, a po drugim pozostał ślad. Na wewnętrznych stronach oprawy przedniej i tylnej znajdują się skrawki rękopisu pochodzącego z drugiej połowy XIII wieku. Kodeks należy do unikalnych i najstarszych graduałów franciszkańskich w Europie, gdyż na stronie 7 zawiera instrukcję dla skryptorów i kantorów, rozpoczynającą się od słów Ista rubrica ponatur in prima pagina gradualium singulorum, nie spotykaną w żadnym rękopisie liturgicznym na zachodzie.

Drugi z eksponowanych graduałów Graduale Romanum Franciscanum ${ }^{15}$ zwany ,średnim”, datowany jest na drugą połowę XIII wieku. Rękopis ten, tak jak i poprzedni, sporządzony został na pergaminie północnym. Kodeks składa się ze 107 kart pergaminowych i 8 papierowych, dołączonych znacznie później, umieszczonych po 4 na początku i na końcu księgi. Karty nie posiadały paginacji naniesionej przez kopistę, sporządzono ją dopiero 25 lipca 1963 r. Paginacja ręczna wykonana została za pomocą liczb nieparzystych na stronach recto $1-213$, bez uwzględnienia kart papierowych. Tekst śpiewów pisany był przez jedną osobę, minuskułą gotycką brunatnym atramentem, w języku łacińskim. Notacja muzyczna kwadratowa nota quadrata na czterech czerwonych liniach. Na jednej stronie znajduje się po dziesięć systemów złożonych z tekstu i melodii. Noty rubrycystyczne wykonane zostały czerwonym i brunatnym atramentem. Szczególną uwagę zwracają większe i mniejsze inicjały w kolorach czerwonym, niebieskim i brunatnym, $\mathrm{z}$ dodatkiem koloru zielonego, z elementami floratury. Treść rękopisu stanowią śpiewy mszalne De tempore i De sanctis oraz Commune sanctorum. Niestety, z powodu wyrwania kart, w kodeksie znajduje się tylko jeden i to niepełny schemat śpiewów Ordinarium missae, zamieszczony na końcu księgi. Oprawę stanowi deska obciągnięta skórą w kolorze jasnobrązowym. Skóra jest mocno przetarta na grzbiecie, licach i brzegach. Pomimo tego widoczne są na niej odciski ślepych tłoków. Ornament tłoczeń na przedniej okładzinie zbudowany jest z szeregu stempli, tworzących trzy bordiury z centralnym polem, podzielonym na cztery kwatery, każda z zaznaczonymi własnymi przekątnymi. Ornament tłoczeń okładziny tylnej ma dwie bordiury, a środkowe pole wypełniają trzy pionowe rzędy stempli. Na obu stronach okładzin zastosowano te same stemple tłoczeń. Zachowały się dwie klamry metalowe i jedna klauzurka.

Ostatni z prezentowanych graduałów Graduale Romanum Franciscanum ${ }^{16}$ zwany „małym”, powstał w 1. połowie XIV wieku. Manuskrypt ten, podobnie jak dwa poprzednie, sporządzony został na pergaminie północnym. Kodeks składa się z 203 kart pergaminowych. W graduale występują dwa rodzaje paginacji. Paginacja rzymska urywa się na 332 stronie. Natomiast paginacja arabska naniesiona została za pomoca liczb nieparzystych na stronach recto $1-405$ oraz stronie verso 406, strony 91-92 są podwójnie paginowane. Paginacja arabska wstawiona została 30 lipca $1963 \mathrm{r}$. Tekst śpiewów pisany był przez trzy osoby, teksturą gotycką czarnym i czerwonym atramentem, w języku łacińskim. Notacja muzyczna kwadratowa nota quadrata na czterech czerwonych liniach. Na jednej stronie

\footnotetext{
${ }^{15}$ BKlar. St. Sącz, sygn. Muz. 2.

${ }^{16}$ BKlar. St. Sącz, sygn. Muz. 3.
} 
znajduje się po osiem systemów złożonych z tekstu i melodii. Noty rubrycystyczne wykonane zostały czarnym i czerwonym atramentem. Inicjały kaligraficzne wykonane zostały piórem, czarnym lub brunatnym atramentem oraz pigmentem w kolorach czerwonym i niebieskim. Rękopis nie był zwyczajną księgą chórową, ale tzw. itinerarium - kodeksem przeznaczonym do codziennego użytku i przydatnym w czasie podróży ${ }^{17}$. Treść rękopisu stanowią części zmienne i części stałe śpiewów mszalnych. Jest to zatem graduał kompletny, zawierający zestaw śpiewów De tempore i De sanctis oraz Commune sanctorum, Ordinarium missae, a także formularze mszy św. wotywnych. W manuskrypcie znalazł się formularz mszalny na uroczystość Bożego Ciała. Podobnie jak w poprzednich dwóch graduałach również i w tym szczególne miejsce zajmują święci franciszkańscy: św. Franciszek i św. Antoni, ale brakuje św. Klary. Ponadto w rękopisie znajduje się komplet 10 mszy św. tworzących Kyriale, podany z dokładnym rozgraniczeniem stopni rytu $^{18}$. Na końcu graduału zamieszczone zostały 33 sekwencje. Oprawę stanowi deska obciągnięta ciemnobrązowym zamszem. Grzbiet oklejony został gładką brązową skórą.

Obok graduałów na wystawie eksponowane były także dwa tomy antyfonarza. Tom pierwszy Antiphonarium Franciscanum, de tempore ${ }^{19}$, datowany jest na 2. połowę XIII wieku. Rękopis ten również wykonany został na pergaminie północnym. Kodeks zawiera 200 kart pergaminowych. Karty nie posiadały paginacji naniesionej przez kopistę, sporządzono ją dopiero 25 sierpnia 1963 r. Paginacja ręczna wykonana została za pomocą liczb parzystych i nieparzystych na stronach recto i verso 1-400. Tekst śpiewów pisany był wczesnogotycką minuskułą czarnym atramentem, w języku łacińskim. Notacja muzyczna kwadratowa nota quadrata na czterech czerwonych liniach. Na jednej stronie znajduje się po dziewięć systemów złożonych z tekstu i melodii. Noty rubrycystyczne wykonane zostały czarnym i czerwonym atramentem. Dekoracja Antiphonarium Franciscanum, de tempore składa się z elementów typowych dla gotyckiego zdobnictwa książkowego $^{20}$. W manuskrypcie znajdują się iluminacje ze scenami figuralnymi w dużych inicjałach, nieskomplikowane dekoracje rysunkowe w mniejszych inicjałach oraz rysunki na dolnych marginesach kart. Tematy kompozycji figuralnych wypełniających 11 dużych inicjałów zostały zainspirowane treściami i porządkiem roku liturgicznego. Szczególną uwagę zwraca miniatura wpisana w inicjał „A", przedstawiająca rzadko spotykaną scenę przyjście Chrystusa w ciele jako Syna Maryi i Jego powtórnego przyjścia w chwale - Paruzji. Napis na wstędze ecce in nubibus filius... venit - oto w oblokach Syn przybywa uzupełniono datą chrztu Polski 996. Pozostałe ilustracje w dużych inicjałach przedstawiają m.in.

${ }^{17}$ Sok, Wplyw klarysek, s. 12.

${ }^{18} \mathrm{H}$. Cempura, Trzynastowieczne liturgiczne rękopisy franciszkańskie $w$ Polsce $w$ świetle wyników badań van Dijka i Walkera, „Archiwa Biblioteki i Muzea Kościelne”, 12 (1966) s. 80; I. Pawlak, Graduaty piotrkowskie jako przekaz choratu gregoriańskiego w Polsce po Soborze Trydenckim, Lublin 1988, s. 103.

${ }^{19}$ BKlar. St. Sącz, sygn. Muz. 4.

${ }^{20}$ B. Miodońska, Małopolskie malarstwo ksiązkowe, w: Malarstwo gotyckie w Polsce, t. 1, Synteza, red. A.S. Labuda, K. Secomska, Warszawa 2004, s. 419. 
Boże Narodzenie, Chrzest Jezusa w Jordanie, Symeona z Dzieciątkiem Jezus na rękach, Chrystusa Zmartwychwstałego, Wizję teofaniczną proroka Izajasza. Miniatury wykonane zostały piórem, brunatnym inkaustem i barwnymi pigmentami w kolorach czerwonym, niebieskim, zielonym, żółtym, brązowym i różowym, w różnych odcieniach, częściowo podkolorowane pędzlem farbami półkryjącymi. Ponadto w rękopisie znajdują się większe inicjały roślinne, a także mniejsze inicjały o motywach figuralnych, antropomorficznych, zoomorficznych i roślinnych oraz bardzo liczne inicjały kaligraficzne. Inicjały wykonane zostały piórem, w kolorach czerwonym, czarnym, niebieskim i zielonym. Większe inicjały figuralne i roślinne obrastają ornamenty linearne z zaczątkami filigranu pączkowego i długich listew wychodzących na marginesy kart. W kodeksie znajdują się rysunki z przedstawieniami figuralnymi, antropomorficznymi, zoomorficznymi i roślinnymi umieszczone na dolnych marginesach kart. Kilka rysunków bezpośrednio nawiązuje do okresu liturgicznego $i$ antyfon $\mathrm{z}$ nim związanych. W brewiarzu na Wielki Piątek, na stronach 243-244 narysowane zostały dwie podobne sceny Ukrzyżowania Pana Jezusa, a na stronie 247 z antyfonami na Wielką Sobotę umieszczono scenę Biczowania Chrystusa. Natomiast pozostałe rysunki postaci ludzkich, zwierząt i ptaków, zamieszczone zostały na dolnych marginesach kart, w różnym okresie liturgicznym ${ }^{21}$. Należy także zaznaczyć, że w rękopisie znajduje się najstarsza kompozycja polifoniczna w Polsce. Na stronie 255, na dolnym marginesie zapisano dwugłosowe Benedicamus Domino. Zapis ten pochodzi prawdopodobnie z 2. połowy XIII wieku. Z punktu widzenia paleografii muzycznej tworzy typową postać tzw. „notacji sylabicznej” stosowanej w rękopisach w XIII i na początku XIV wieku. Notacja ta była bezpośrednio związana z conductem i pokrewnymi mu formami wielogłosowych opracowań tropów, sekwencji i innych teksów liturgicznych ${ }^{22}$. Drugi głos powtarza w zapisie notację chorałową Benedicamus Domino, wpisaną w tekście zasadniczym rękopisu, w bezpośrednim sąsiedztwie z polifonicznymi dopiskami. Oprawę stanowi deska obciągnięta brązową skórą. Od strony wewnętrznej okładziny oprawy wzmocnione są papierem.

Tom drugi Antiphonarium Franciscanum, de sanctis ${ }^{23}$, datowany jest na 2. połowę XIII wieku. Manuskrypt ten także sporządzony został na pergaminie północnym. Kodeks składa się z 135 kart pergaminowych i 41 kart papierowych, dołączonych w późniejszym czasie, rozmieszczonych w różnych miejscach rękopisu. Karty nie posiadały paginacji naniesionej przez kopistę, wstawiono ją dopiero 23 lipca 1963 r. Paginacja ręczna wykonana została za pomocą liczb nieparzystych na stronach recto 1-269, bez uwzględnienia dodatków papierowych. Tekst śpiewów pisany był wczesnogotycką minuskułą czarnym atramentem, w języku łacińskim. Notacja muzyczna kwadratowa nota quadrata na czterech czerwonych liniach. Na jednej stronie znajduje się po dziewięć systemów złożonych z tekstu i melodii. Noty rubrycystyczne wykonane zostały czerwonym i czarnym atra-

${ }^{21}$ Zob. Z. Kliś, Probae Pennae. Rysunki $w$ antyfonarzu sądeckim z XIII wieku, „Analecta Cracoviensia", 38-39 (2006-2007) s. 455-467.

${ }^{22}$ A. Sutkowski, Początki polifonii średniowiecznej w Polsce w świetle nowych źródel, „Muzyka”, $6(1961)$ nr 1, s. 15.

${ }^{23}$ BKlar. St. Sącz, sygn. Muz. 5. 
mentem. Szczególną uwagę zwracają trzy większe inicjały figuralne. Na stronie 1 inicjał ,D” ze sceną powołania przez Jezusa św. Andrzeja na apostoła, na stronie 154 inicjał „A" z postacią anioła oraz na stronie 184 inicjał „C" z wizerunkiem św. Cecylii, patronki śpiewu i muzyki. Miniatury, podobnie jak w tomie pierwszym, wykonane zostały piórem, brunatnym inkaustem i barwnymi pigmentami w kolorach czerwonym, niebieskim, zielonym i brązowym, w różnych odcieniach, częściowo podkolorowane pędzlem farbami półkryjącymi. Ponadto $\mathrm{w}$ rękopisie znajdują się większe inicjały roślinne, a także mniejsze inicjały o motywach figuralnych, antropomorficznych, zoomorficznych i roślinnych oraz bardzo liczne inicjały kaligraficzne. Inicjały wykonane zostały piórem, w kolorach czerwonym, czarnym, niebieskim i zielonym. W tomie drugim nie zabrakło też rysunków, z przedstawieniami figuralnymi, zoomorficznymi i roślinnymi, umieszczonych na dolnych marginesach kart. Treść rękopisu stanowią antyfony i responsoria brewiarzowe na uroczystości świętych. Oprawę stanowi deska obciągnięta brązową skórą z mocno wytartymi śladami ślepych tłoczeń na okładzinie przedniej i tylnej. Naroża wzmocniono dodatkowymi kawałkami skóry. Grzbiet oklejony został brązowym zamszem. Przy zewnętrznej krawędzi okładziny tylnej zamocowano w desce za pomocą skórzanych pasków dwie miedziane blaszki zakończone płaskim, szerokim wygięciem, które wpasowują się w metalowy uchwyt zapinek na przedniej okładzinie.

W jednym z najstarszych żywotów św. Kingi czytamy, że codziennie ze swymi siostrami przed wyjściem z kościoła odmawiała dziesięć psalmów w języku gminnym - in vulgari, jak w przeciwieństwie do łaciny nazywano język rodzimy ludu, dodając modlitwę do Wszechmogącego Boga na intencję Kościoła powszechnego $^{24}$. Czy na pewno odmawiała psałterz po polsku, czy tylko kończyła psalmy słowami polskimi? Niestety, tego dzisiaj nie wiemy. „W każdym razie - jak pisze Juliusz Kleiner - wiąże się z postacią świętej ślad wyraźny wnikania mowy polskiej w łacinę nabożeństwa"25. Psałterz był jedną z najstarszych i podstawowych ksiąg liturgicznych. Zawierał teksty biblijnej Księgi Psalmów. Początkowo psalmy były ułożone w kolejności od 1 do 150 , następnie - zgodnie z potrzebami liturgii - w porządku tygodniowym, rozdzielone na poszczególne godziny kanoniczne i uzupełnione hymnami oraz kantykami biblijnymi czyli modlitwami w formie pieśni. W ten sposób psałterz dopełniony zapisami muzycznymi stał się podstawową księgą do odmawiania wspólnych modlitw i chóralnego śpiewu zakonników i duchowieństwa diecezjalnego. Od XIII wieku psałterz upowszechnił się jako modlitewnik ludzi świeckich. Dlatego też język łaciński był przekładany na języki narodowe, w tym na polski ${ }^{26}$. Na wystawie prezentowany był Psałterz pochodzący z przełomu XIII i XIV wieku ${ }^{27}$. Rękopis ten również sporządzony został na pergaminie północnym. Kodeks zawiera 223 karty pergaminowe, numerowane ręcznie ołówkiem. Brakuje w nim 4 kart na początku, a także 4 kart

${ }^{24}$ Vita et miracula sanctae Kyngae ducissae Cracoviensis, wydał W. Kętrzyński, w: Monumenta Poloniae Historica, t. 4, Lwów 1884, s. 706.

${ }^{25}$ J. Kleiner, Zarys dziejów literatury polskiej, Wrocław 1972, s. 22.

${ }^{26}$ B. Miodońska, Matopolskie malarstwo książkowe 1320-1540, Warszawa 1993, s. 207-208.

${ }^{27}$ BKlar. St. Sącz, sygn. rkps 1. 
między: 175-176, 191-192, 198-199 i 199-200 oraz 4 kart na końcu. Występuje kilka pomyłek w numeracji poszczególnych kart. Karty na obrzeżach są barwione na kolor czerwony. Kodeks składa się z dwóch części. W pierwszej z nich od 1 do 175 karty zamieszczony został psałterz, a w drugiej od 176 do 223 karty mieści się hymnarz. Tekst psalmów pisany był rotundą czarnym atramentem, w języku łacińskim. Szczególną uwagę zwracają starannie wykonane większe i mniejsze inicjały w kolorze czerwonym i niebieskim. Obrastają je ornamenty linearne z zaczątkami filigranu pączkowego i długich listew wychodzących na marginesy kart. Inicjały kaligraficzne są także w kolorach czerwonym i niebieskim. Tekst hymnów pisany był teksturą gotycką czarnym atramentem, w języku łacińskim. Większe i mniejsze inicjały są w kolorze czerwonym. Oprawę stanowi deska obciągnięta jasnobrązową skórą.

$\mathrm{Na}$ wystawie prezentowany był jeden $\mathrm{z}$ dwóch średniowiecznych żywotów św. Kingi. Vita beatae Cunegundis autorstwa Jana Długosza ${ }^{28}$, bo o nim mowa, powstał w latach 1471-1473. Kodeks składa się z 66 kart pergaminowych, paginowanych ręcznie prawdopodobnie przez kopistę. Dwie pierwsze karty nieliczbowane zostały wyrwane. W oprawę wierzchnią rękopisu wklejono 15 kart papierowych, dołączonych w XIX wieku, umieszczonych na początku kodeksu, ponumerowanych ołówkiem. Tekst w całości rubrowany, pisany był pod okiem autora, przez Krzysztofa z Dębowca, wikariusza i notariusza katedry na Wawelu, w jednej kolumnie na kartach liniowanych atramentem. W kilku miejscach w tekście widoczne są drobne poprawki i uzupełnienia wprowadzone przez Długosza. $\mathrm{Na}$ karcie 14 recto na dolnym marginesie znajduje się jego najdłuższy własnoręczny dopisek. Na ostatniej stronie kodeksu na końcu tekstu widnieje sporządzony brązowym atramentem dopisek: ANNO 1473 MONS. Ponadto w rękopisie znajdują się marginalne zapiski i nieliczne poprawki pochodzące z XVI wieku. W tekście uwagę zwracają ozdobne inicjały w kolorach czerwonym, niebieskim i zielonym. Długosz w Vita beatae Cunegundis powtórzył niezmienione treści hagiograficzne pochodzące z najstarszego Vita sanctae Kyngae ducissae Cracoviensis, powstałego w kręgu franciszkanów małopolskich w latach 1317-1320, w oparciu o bogaty materiał źródłowy, a także ze zbioru pośmiertnych Miracula z 1329 r., będącego nową redakcją pierwszych protokołów cudów sporządzonych przy grobie Kingi w latach 1307-1312. Następnie dodał do niego opis cudów spisanych w klasztorze w latach 1405-1471, uporządkował całość, nadał porządek chronologiczny i logiczny oraz kształt artystyczny. Swoje dzieło zadedykował biskupowi krakowskiemu Jakubowi z Sienna z myślą o skłonieniu go do podjęcia starań o kanonizację Kingi ${ }^{29}$. Na pierwszej karcie kodeksu znajdowała się prawdopodobnie dedykacja i miniatura przedstawiająca klęczącego Jana Długosza ofiarującego swe dzieło Kindze. Tekst Vita beatae Cunegundis w przekładzie polskim ks. Przecława Mojeckiego, doktora teologii i spowiednika klarysek, jako Zywot S. Kunegundy Zakonu Swiętey Klary Xięzny Polskiey wydrukowany został

${ }^{28}$ BKlar. St. Sącz, sygn. rkps 3.

${ }^{29}$ A. Witkowska, Bt. Kinga $w$ średniowiecznych przekazach hagiograficznych, „Tarnowskie Studia Teologiczne", 10 (1986) cz. 1, s. 274; J. Dybiec, Błogostawiona Kinga w legendzie, literaturze, nauce, „Rocznik Sądecki”, 27 (1999) s. 21. 
w 1617 r. w oficynie Franciszka Cezarego w Krakowie. Natomiast w wersji oryginalnej znalazł się w tomie pierwszym wydania zbiorowego dzieł Jana Długosza Opera omnia (Cracoviae 1887) w opracowaniu Ignacego Polkowskiego i Żegoty Paulego. Rękopis został ofiarowany przez Długosza klaryskom 18 maja $1474 \mathrm{r}$. (podawana jest też data 8 maja 1474 r.) i do 1684 r. znajdował się w bibliotece klasztornej, skąd wypożyczono go kapitule krakowskiej na potrzeby procesu beatyfikacyjnego, który wszczęto po raz kolejny z inicjatywy króla Jana III Sobieskiego. Autograf powrócił do klasztoru w 1691 r. Następnie przetrwał szczęśliwie okres wojny północnej (1700-1721) i związane z nim przemarsze wojsk oraz pożar klasztoru w 1764 r. Uratowany został też podczas kasaty i rabunku biblioteki klasztornej w 1782 r. Około 1824 r. rękopis wypożyczył ks. Michał Serwusiński, katecheta i dyrektor klasztornej szkoły żeńskiej. W 1831 r. Żegota Pauli podczas zwiedzania Starego Sącza i wizyty w klasztorze ,widział - go u jednej osoby tamtejszej" ${ }^{30}$. Po śmierci ks. Serwusińskiego w 1833 r. klaryski rozpoczęły starania o odzyskanie księgozbioru, a rękopis miał wówczas w posiadaniu ks. Michał Głowacki, wikary w Poroninie, który w 1846 r. został uwięziony w Nowym Sączu za udział w powstaniu chochołowskim. Umierając ks. Głowacki zlecił aby rękopis został zwrócony klasztorowi w Starym Sączu. Niestety, poszukiwania $\mathrm{w}$ jego bibliotece okazały się bezowocne ${ }^{31}$. Dopiero odwiedziny w starosądeckim klasztorze Józefa Łepkowskiego i Józefa Jerzmanowskiego, którzy w 1849 r. odbywali podróż naukową po Galicji, wznowiły poszukiwania. Ich apele drukowane $\mathrm{w}$ czasopismach ${ }^{32}$ przyczyniły się do odnalezienia księgi w 1852 r. we Lwowie w zbiorach hr. Włodzimierza Dzieduszyckiego, który zdecydował się na zwrot dzieła, choć wcześniej złożył ofertę jego zakupu za 400 guldenów. Siostry nie wyraziły zgody na transakcję i za pośrednictwem ks. Franciszka Szlosarczyka, rękopis został przekazany kapitule tarnowskiej, a 29 października 1854 r. powrócił do klasztoru w Starym Sączu ${ }^{33}$. Wypożyczony został potem jeszcze raz w maju 1880 r. na uroczystości związane z rocznicą 400-lecia śmierci Jana Długosza. Do Vita beatae Cunegundis dołączonych zostało 10 dokumentów-listów, które opisują losy księgi i jej poszukiwania oraz zawierają informacje dotyczące św. Kingi i dynastii Arpadów. Oprawę stanowi deska obciągnięta mocno przetartą brązową skórą, na której zachowały się do dzisiaj słabo widoczne odciski ślepych tłoków z elementami linii geometrycznych oraz jedna metalowa klauzurka górna na oprawie tylnej. Na wewnętrznej stronie okładek przedniej i tylnej na skórze znajdują się zatarte zapiski.

${ }^{30}$ Ż. Pauli, Wyimki z podróży po Galicji w r. 1831, „Rozmaitości”, (1835) nr 51, s. 411.

${ }^{31}$ Zob. W.J. Kowalów, Tajemnicze losy ,,Vita Beatae Cunegundis” i ich zwiazek z ks. Michałem Gtowackim, „Rocznik Sądecki”, 26 (1998) s. 116-119.

${ }^{32}$ Zob. J. Łepkowski, J. Jerzmanowski, O zgubionym autografie Długosza z klasztoru klarysek w Starym Saczu, „Dodatek Literacki” do „Czasu”, (1849) nr 5, s. 2-3; J. Łepkowski, J. Jerzmanowski, Ułamek z podróży archeologicznej po Galicji odbytej w r. 1849, „Biblioteka Warszawska”, 3 (1850) s. 439-441; J. Łepkowski, Listy z Galicji IV, „Czas”, (1851) nr 193, s. 1.

${ }^{33}$ Zob. K. Karolczak, , ,Vita beatae Cunegundis” jako przedmiot sporu starosadeckich Klarysek z Włodzimierzem hr. Dzieduszyckim, ,Rocznik Sądecki”, 27 (1999) s. 33-35. 
Ponadto na wystawie eksponowane były także najciekawsze stare druki pochodzące ze zbiorów biblioteki klasztornej, świadczące o wysokim poziomie intelektualnym konwentu starosądeckiego. Księgozbiór klarysek powiększał się dzięki zakupom książek przez ksienie i siostry. W dekrecie powizytacyjnym z 1599 r. kardynał Jerzy Radziwiłł nakazywał, aby: „,książki wszelakie polskie do nabożeństwa służące, $[\ldots]$ ksieni skupowała dla Panien przez kapłany, kiedy do Krakowa jadą"34. Część księgozbioru stanowiły również dary od osób duchownych. Największym ofiarodawcą był ks. Sebastian Machowicz, który w 1680 r. przekazał 32 książki ${ }^{35}$. Także wiele dziewcząt wstępujących do klasztoru przywoziło ze sobą własne książki. Podpisy i notatki własnościowe dowodzą tego, że książki przechodziły między siostrami z pokolenia na pokolenie, a niektóre klaryski miały ich po kilkanaście. Wielką miłośniczką książek była Katarzyna Eufrozyna Siemieńska (†1738), ksieni klasztoru klarysek w latach 1723-1729. Posiadała 13 tomów, co na owe czasy i na siostrę zakonu kontemplacyjnego, świadczyło o jej dużym zamiłowaniu do książek, jakiego trudno było się dopatrzyć u innych przeorysz ${ }^{36}$. Do niej należał prezentowany na wystawie Zamek Wnętrzny, abo Gmachy Dusze Ludzkiey ${ }^{37}$ autorstwa św. Teresy od Pana Jezusa, fundatorki karmelitów i karmelitanek bosych, przetłumaczony z języka włoskiego na język polski przez ks. Sebastiana Nuceryna, wydrukowany w 1633 r. w oficynie Franciszka Cezarego w Krakowie. Na wewnętrznej stronie przedniej okładziny obok swego podpisu umieściła także życzenie: „Proszę, aby mi tych książek nie brać, gdy pożyczą do czytania, oddać". Książka ta należała również do Konstancji Reklewskiej (†1796), ksieni klasztoru klarysek w latach 1761-1764, o czym świadczy jej podpis. Wspólnie z Zamkiem Wnętrznym oprawione zostały Rozmyślania Męki niewinney Pana naszego Iezvsa Krystvsa, z modlitwami. Przy tym Różany Wianek najświętszey Panny Maryey $^{38}$, wydrukowane przez Jakuba Siebeneichera w 1595 r. w Krakowie. Modlitewnik ten cieszył się dużą popularnością. Jego autorką miała być podobno Anna Siebeneicherowa, żona Jakuba Siebeneichera, która zadedykowała tomik bezimiennie królowej Annie Jagiellonce, podpisując się dopiero w edycji z 1608 r. pod dedykacją dla Konstancji Rakuszanki, żony Zygmunta III $^{39}$. Książeczkę wzbogaca 17 drzeworytów. Oprawa tekturowa jest nieco uszkodzona. Kolejna prezentowana pozycja to Oktawa vprzedzaiaca święto Błogosławioney Matki Kvnegvndi ${ }^{40}$ wydana bezimiennie, prawdopodobnie w XVII wieku w Krakowie. Książeczka ta była własnością trzech zakonnic: Anny Wilkoszowskiej, Zofii Benedykty Stanówny (†1682), ksieni klarysek w latach 1672-1675 i Teresy Alojzy

\footnotetext{
${ }^{34}$ AKlar. St. Sącz, sygn. Rf/a-1, Reformatia, k. 16.

${ }^{35}$ AKlar. St. Sącz, sygn. BK/j-42, W. Bazielich, Dawne biblioteki Starego Sacza, Kraków 1952,

${ }^{36}$ W. Bazielich, Klaryski starosądeckie a sztuki piękne w XVII i XVIII wieku, „Nasza Przeszłość”,

${ }^{37}$ BKlar. St. Sącz, sygn. Cim. Q. 108.

${ }^{38}$ BKlar. St. Sącz, sygn. Cim. Q. 109.

${ }^{39}$ A. Mańkowska, Siebeneicher Jakub, w: Drukarze dawnej Polski od XV do XVIII wieku, t. 1, Małopolska, cz. 1, Wiek XV-XVI, red. A. Kawecka-Gryczowa, Wrocław 1983, s. 193.

${ }^{40}$ BKlar. St. Sącz, sygn. BK/he-1.
} s. 14. 25 (1966) s. 206. 
Piotrowskiej (†1778), mistrzyni duchownej. Zachowała się oprawa, którą stanowi gruby pergamin z dobrze widocznymi ślepymi tłoczeniami o motywach roślinnych w narożnikach na przedniej i tylnej okładzinie. Na przedniej okładzinie w zwierciadle odciśnięto owalną plakietę przedstawiającą Pana Jezusa na krzyżu, a nad nim gołębicę z rozpostartymi skrzydłami, poniżej narzędzia męki. Natomiast na tylnym licu pośrodku odciśnięto plakietę z wizerunkiem Matki Bożej trzymającej Dzieciątko Jezus na prawym ręku. Maria ukazana w promienistej glorii, stoi na półksiężycu i depcze węża. Po bokach owalu na przedniej i tylnej okładzinie odciśnięto po cztery małe listki. Następne trzy eksponowane stare druki oprawione zostały wspólnie. Pierwszy z nich to Zabawy dvchowne Pannom Zakonu Świętego Benedykta przodkiem, a potym y wszystkim inym Zakonniczkom bardzo potrzebne y pożyteczne ${ }^{41}$ tłoczony w 1597 r. w drukarni Łazarzowej w Krakowie. Drugi to modlitewnik Modl się do Nog Iego upadaiac ${ }^{42}$ wydany bezimiennie, bez daty i miejsca wydania, a trzeci stanowią Akty strzeliste stużace do zabaw całego dnia ${ }^{43}$ wydrukowane w 1690 r. w oficynie Franciszka Cezarego w Krakowie. Egzemplarz ten był w posiadaniu Józefy Petroneli Zdzieńskiej (†1838), ksieni klasztoru klarysek w latach 1811-1835. Do dzisiaj zachowała się skórzana oprawa w kolorze ciemnobrązowym $\mathrm{z}$ widocznymi ślepymi tłoczeniami na przedniej i tylnej okładzinie. Oprawę uzupełniają dwie klamerki na brzegach (na przedniej okładzinie brak zatrzasku w górnej części) i dwie klauzurki skórzane z metalowymi aplikacjami w kształcie wydłużonego serca.

Zbiory klasztoru klarysek w Starym Sączu są bardzo duże i różnorodne. Prezentowana wystawa Dziedzictwo kulturowe świętej Kingi umożliwiła wszystkim zainteresowanym pogłębienie wiedzy o kulturze artystycznej i spuściźnie kulturowej starosądeckiego konwentu. Uświadomiła ona również ważną rolę św. Kingi w podtrzymywaniu zachwianej w okresie rozbicia dzielnicowego Polski państwowości polskiej, która czerpiąc z bogatej duchowości franciszkańskiej ukształtowała na trwałe religijny wizerunek Sądecczyzny oraz społeczne i gospodarcze oblicze Małopolski.

Słowa kluczowe: Stary Sącz; św. Kinga; klaryski; zbiory muzyczne; biblioteka klasztorna

\footnotetext{
${ }^{41}$ BKlar. St. Sącz, sygn. Cim. 0.3.

${ }^{42}$ BKlar. St. Sącz, sygn. Cim. 0.4.

${ }^{43}$ BKlar. St. Sącz, sygn. Cim. 0.5.
} 


\section{BIBLIOGRAFIA}

\section{Źródła rękopiśmienne}

Archiwum SS. Klarysek w Starym Sączu, sygn. Rf/a-1, Reformatia od Jego Xancti M. Xiędza Jerzego Cardinała Radziwiłła Biskupa Krakowskiego, Pannom Klasztoru Starosądeckiego zostawiona Roku 1599 dnia X sierpnia.

Archiwum SS. Klarysek w Starym Sączu, sygn. BK/j-42, Bazielich Wiktor, Dawne biblioteki Starego Sącza, Kraków 1952.

\section{Źródła drukowane}

Kodeks Dyplomatyczny Małopolski, wydał i przypisami objaśnił Franciszek Piekosiński, t. 2, Kraków 1886.

Vita et miracula sanctae Kyngae ducissae Cracoviensis, wydał Wojciech Kętrzyński, w: „Monumenta Poloniae Historica”, t. 4, Lwów 1884, s. 662-744.

\section{Opracowania}

Bazielich Wiktor, Klaryski starosądeckie a sztuki piękne w XVII i XVIII wieku, „Nasza Przeszłość", 25 (1966) s. 179-220.

Budkowa Zofia, Kunegunda, w: Polski Słownik Biograficzny, t. 16, Wrocław 1971, s. 186-189.

Cempura Henryk, Kultura muzyczna klasztoru PP. Klarysek w Starym Sączu w latach 1700-1782, Tarnów 2009.

Cempura Henryk, Trzynastowieczne liturgiczne rękopisy franciszkańskie w Polsce w świetle wyników badań van Dijka i Walkera, „Archiwa Biblioteki i Muzea Kościelne”, 12 (1966) s. 75-82.

Dybiec Julian, Błogosławiona Kinga w legendzie, literaturze, nauce, „Rocznik Sądecki”, 27 (1999) s. 20-32.

Dziedzictwo kulturowe świętej Kingi. Katalog wystawy zrealizowanej ze zbiorów klasztoru Sióstr Klarysek w Starym Sączu, red. nauk. R. Ślusarek, Nowy Sącz 2013.

Encyklopedia wiedzy o książce, Wrocław 1971.

Garnczarski Stanisław, Kultura muzyczna w klasztorze klarysek w Starym Sączu, „Tarnowskie Studia Teologiczne", 33 (2014) nr 2, s. 127-136.

Karolczak Kazimierz, „Vita beatae Cunegundis” jako przedmiot sporu starosądeckich Klarysek z Włodzimierzem hr. Dzieduszyckim, „Rocznik Sądecki”, 27 (1999) s. 3335.

Kleiner Juliusz, Zarys dziejów literatury polskiej, Wrocław 1972.

Kliś Zdzisław, Probae Pennae. Rysunki w antyfonarzu sądeckim z XIII wieku, „Analecta Cracoviensia", 38-39 (2006-2007) s. 455-467.

Kowalów Witold Józef, Tajemnicze losy „Vita Beatae Cunegundis” i ich związek z ks. Michałem Głowackim, „Rocznik Sądecki”, 26 (1998) s. 116-119.

Łepkowski Józef, Listy z Galicji IV, „Czas”, (1851) nr 193, s. 1.

Łepkowski Józef, Jerzmanowski Józef, O zgubionym autografie Długosza z klasztoru klarysek w Starym Sączu, „Dodatek Literacki” do „Czasu”, (1849) nr 5, s. 2-3.

Łepkowski Józef, Jerzmanowski Józef, Ułamek z podróży archeologicznej po Galicji odbytej w r. 1849, „Biblioteka Warszawska”, 3 (1850) s. 416-454.

Mańkowska Anna, Siebeneicher Jakub, w: Drukarze dawnej Polski od XV do XVIII wieku, t. 1, Małopolska, cz. 1, Wiek XV-XVI, red. A. Kawecka-Gryczowa, Wrocław 1983, s. 191-200. 
Miodońska Barbara, Małopolskie malarstwo książkowe, w: Malarstwo gotyckie w Polsce, t. 1, Synteza, red. A. S. Labuda, K. Secomska, Warszawa 2004, s. 413-449.

Miodońska Barbara, Małopolskie malarstwo książkowe 1320-1540, Warszawa 1993.

Misiurek Jerzy, Kinga, Kunegunda, w: Encyklopedia katolicka, t. 8, red. B. Migut, Lublin 2000, kol. 1450-1451.

Pauli Żegota, Wyimki z podróży po Galicji w r. 1831, „Rozmaitości”, (1835) nr 51, s. 410-411.

Pawlak Ireneusz, Graduały piotrkowskie jako przekaz chorału gregoriańskiego w Polsce po Soborze Trydenckim, Lublin 1988.

Przybyłowicz Olga Miriam, Zarys dziejów klasztoru SS. Klarysek w Starym Sączu, w: Dziedzictwo kulturowe świętej Kingi. Katalog wystawy zrealizowanej ze zbiorów klasztoru Sióstr Klarysek w Starym Sączu, red. nauk. R. Ślusarek, Nowy Sącz 2013, s. 1-7.

Sok Janusz, Wpływ klarysek starosądeckich na rozwój kultury liturgiczno-muzycznej na przełomie XIII i XIV wieku, ,Studia Redemptorystowskie”, (2008) nr 6, s. 9-19.

Sutkowski Adam, Początki polifonii średniowiecznej w Polsce w świetle nowych źródeł, „Muzyka”, 6 (1961) nr 1, s. 3-22.

Szwarga Kazimierz, Błogosławiona Kinga, Warszawa 1989.

Witkowska Aleksandra, B1. Kinga w średniowiecznych przekazach hagiograficznych, „Tarnowskie Studia Teologiczne”, 10 (1986) cz. 1, s. 274-282.

Witkowska Maria Helena, Kinga, Kunegunda, w: Hagiografia polska. Słownik bio-bibliograficzny, t. 1, red. R. Gustaw, Poznań 1971, s. 757-772.

\section{ST KINGA'S CULTURAL HERITAGE. FROM THE LIBRARY COLLECTION OF THE POOR CLARES IN NOWY SĄCZ}

\section{Summary}

From 14 June to 25 August 2013, the „Dawna Synagoga” Gallery, one of the branches of the District Museum in Nowy Sącz, hosted the exhibition „St Kinga's Cultural Heritage". The purpose of this exhibition was to show a wider audience the artistic heritage of the Poor Clares Monastery in Stary Sacz. Most of the exhibits were presented outside the monastery walls for the first time. Among them were items belonging to St Kinga, valuable works of handicraft, the oldest written texts, as well as sculptures and paintings of high artistic value from the 15 th to the 18 th centuries.

Keywords: Stary Sącz; St Kinga; the Poor Clares; music collections; monastery library 


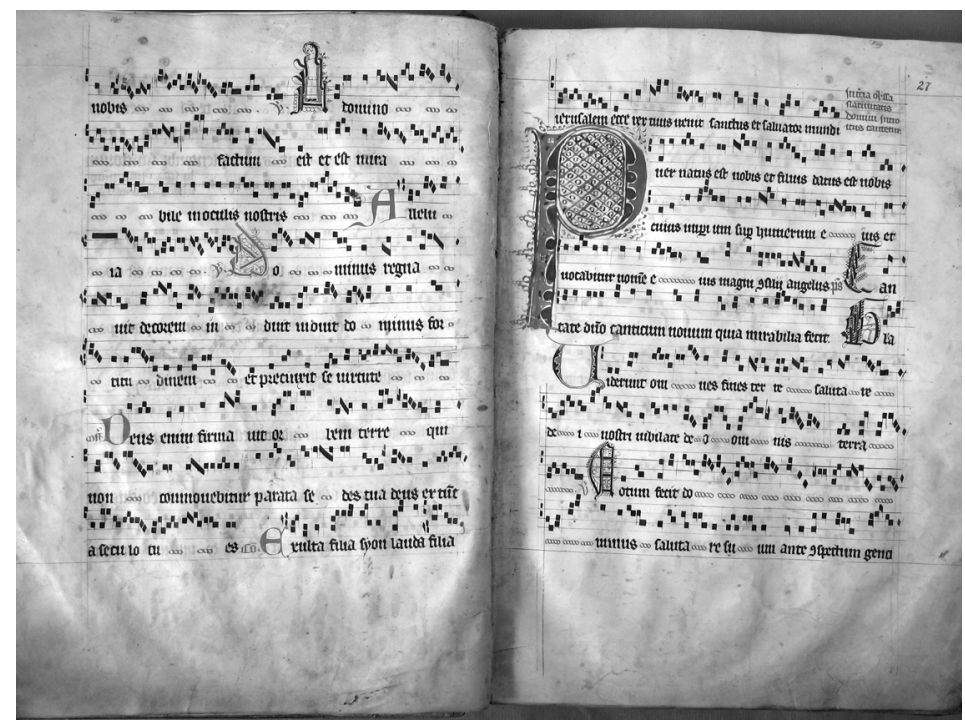

Fot. 1. Graduale Romanum Franciscanum zwany „dużym”, 2. poł. XIII wieku, sygn. Muz. 1. Fot. Katarzyna Grochowska.

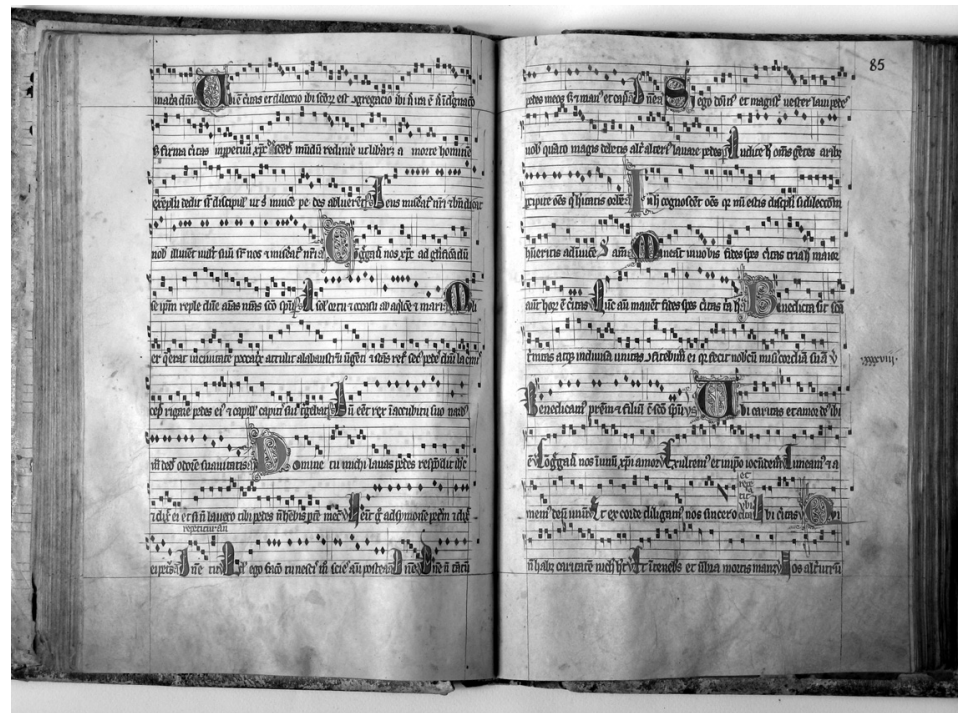

Fot. 2. Graduale Romanum Franciscanum zwany „średnim”, 2. poł. XIII wieku, sygn. Muz. 2. Fot. Katarzyna Grochowska. 


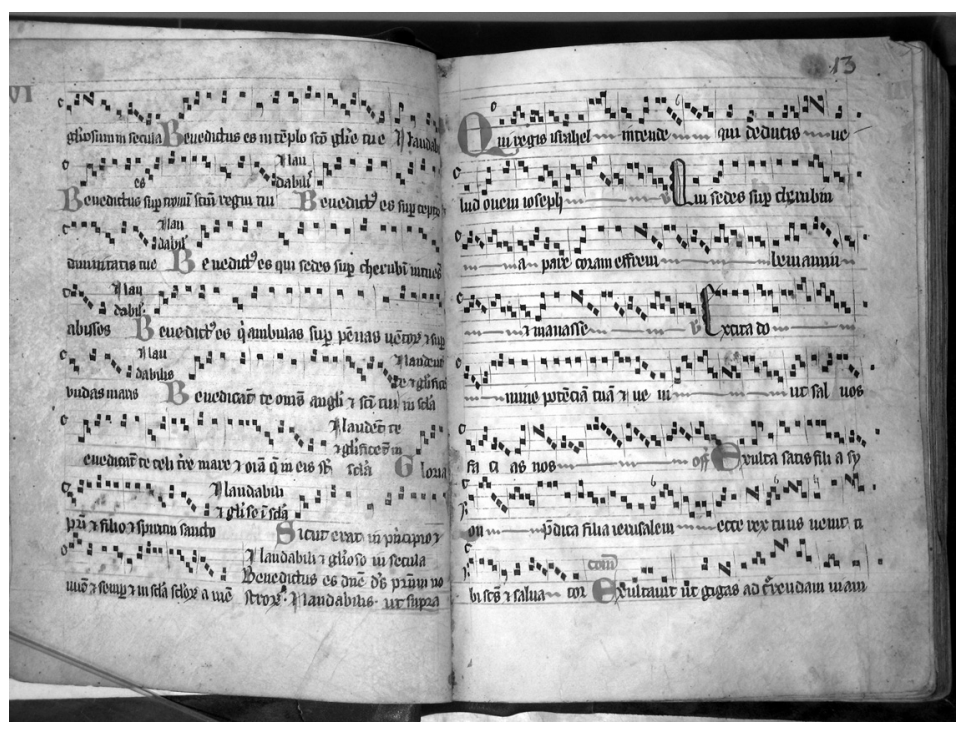

Fot. 3. Graduale Romanum Franciscanum zwany „małym”, 1. poł. XIV wieku, sygn. Muz. 3. Fot. Katarzyna Grochowska.

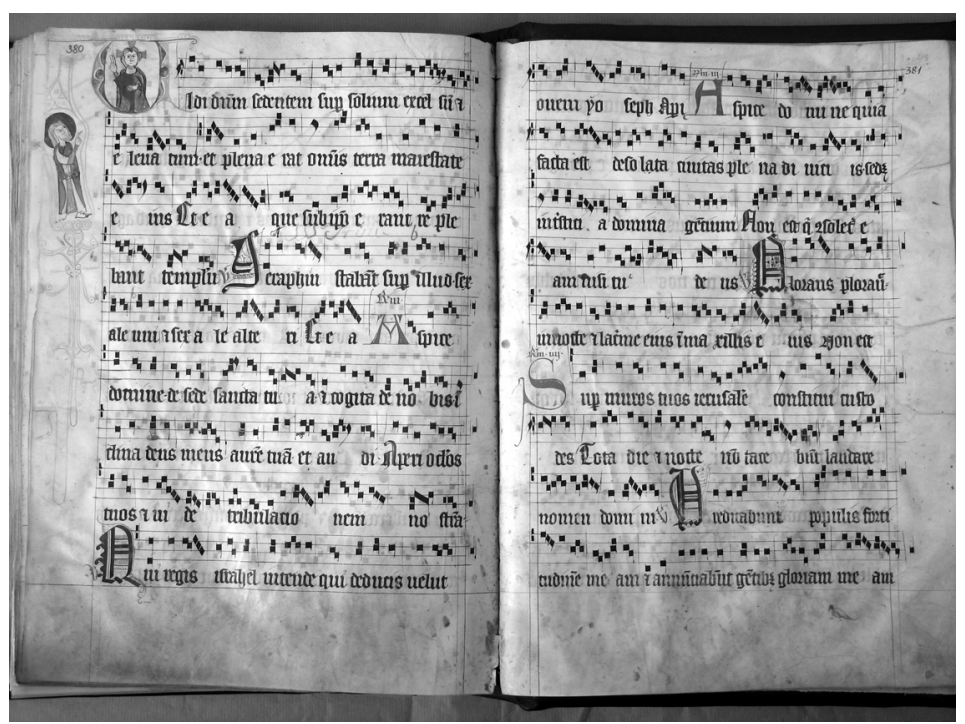

Fot. 4. Antiphonarium Franciscanum, de tempore, 2. poł. XIII wieku, sygn. Muz. 4. Fot. Katarzyna Grochowska. 


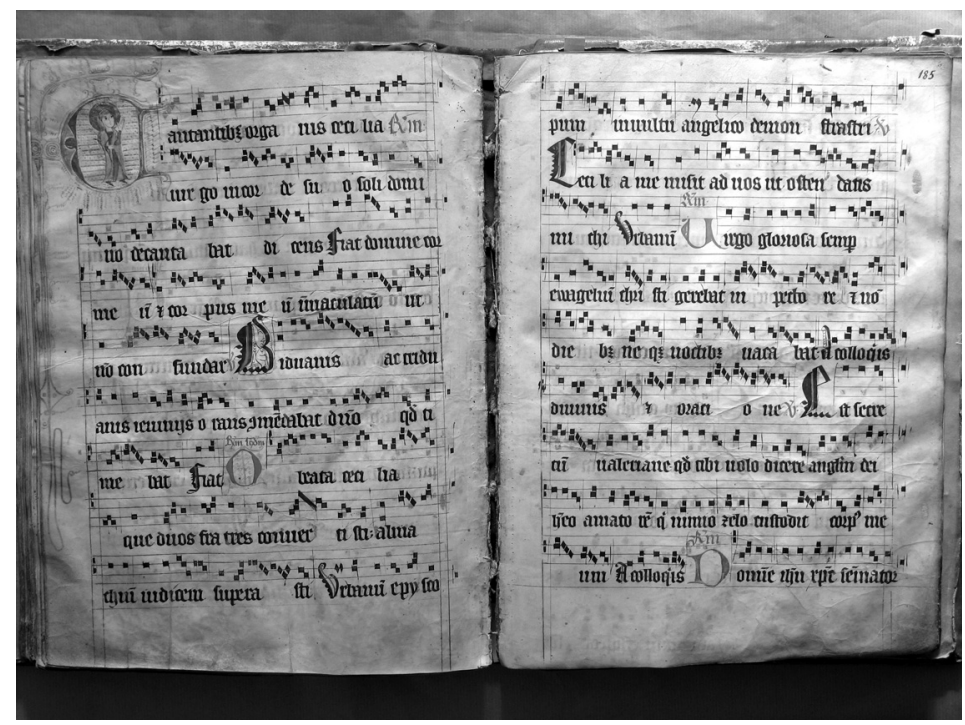

Fot. 5. Antiphonarium Franciscanum, de sanctis, 2. poł. XIII wieku, sygn. Muz. 5. Fot. Katarzyna Grochowska.

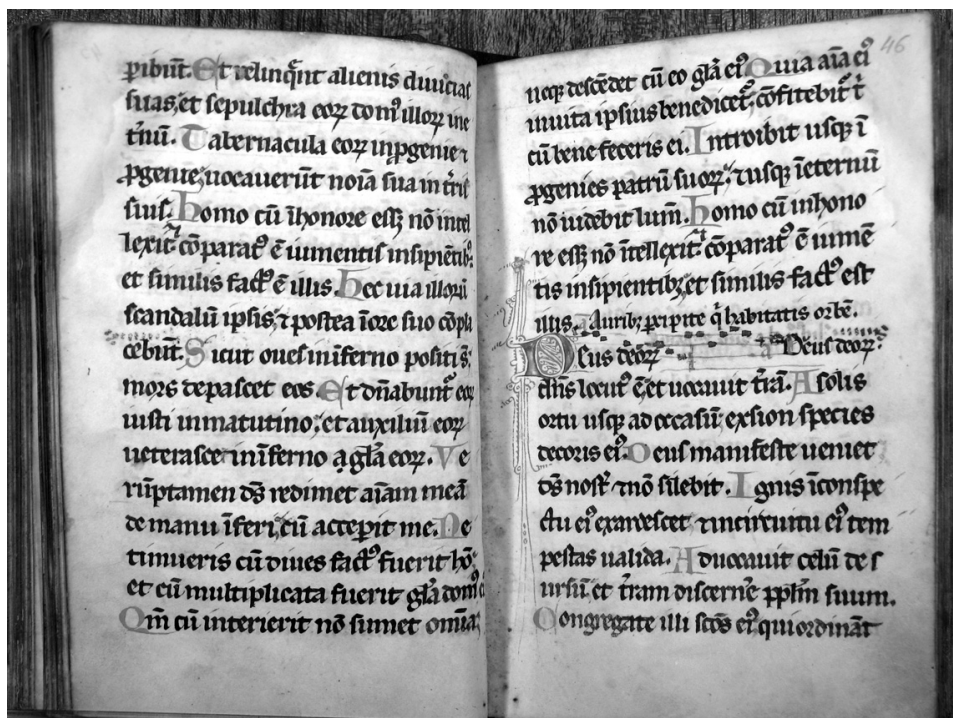

Fot. 6. Psałterz, przełom XIII i XIV wieku, sygn. rkps 1.

Fot. Katarzyna Grochowska. 


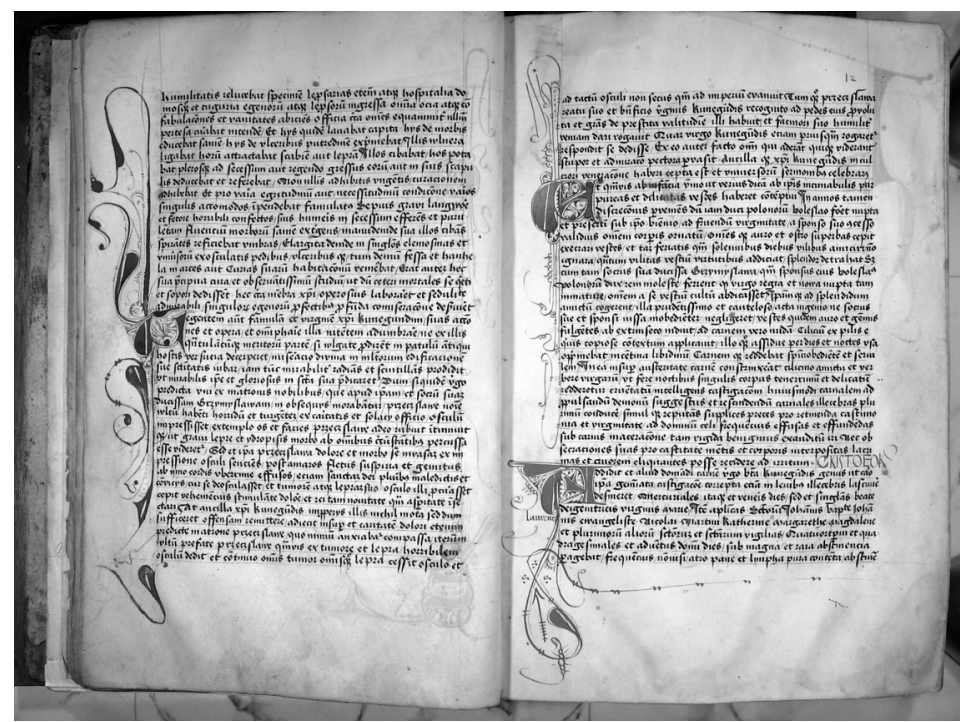

Fot. 7. Jan Długosz, Vita beatae Cunegundis, sygn. rkps 3. Fot. Katarzyna Grochowska.

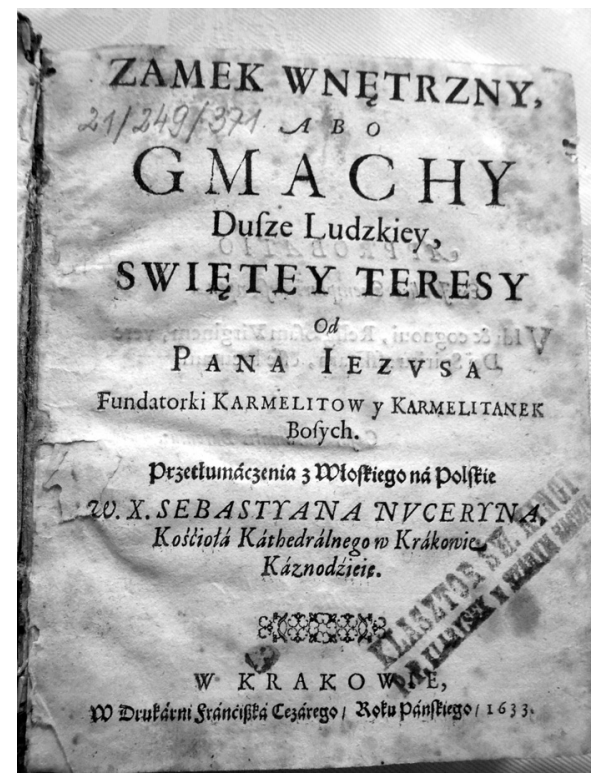

Fot. 8. Karta tytułowa: św. Teresa od Pana Jezusa, Zamek Wnętrzny, abo Gmachy Dusze Ludzkiey, Kraków 1633, sygn. Cim. Q. 108.

Fot. Małgorzata Mirek. 


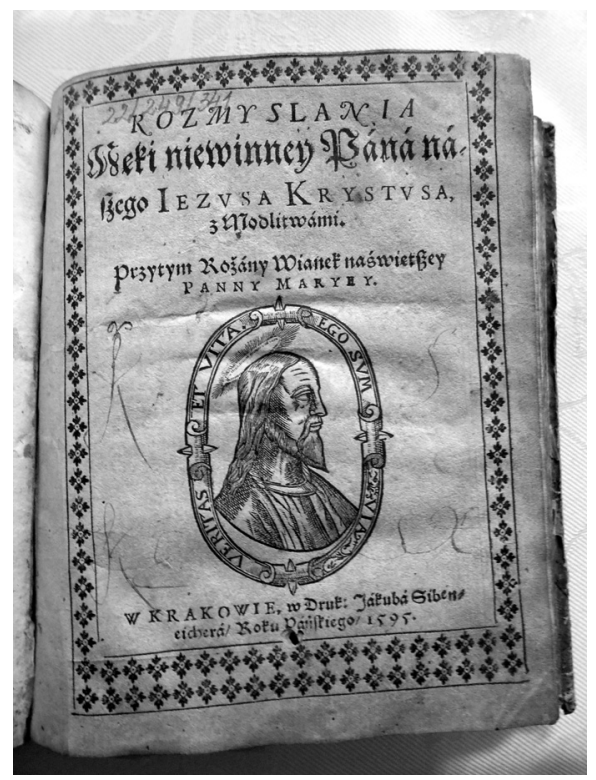

Fot. 9. Karta tytułowa: Rozmyślania Męki niewinney Pana naszego Iezvsa Krystvsa, z modlitwami. Przy tym Różany Wianek najświętszey Panny Maryey, Kraków 1595, sygn. Cim. Q. 109. Fot. Małgorzata Mirek.

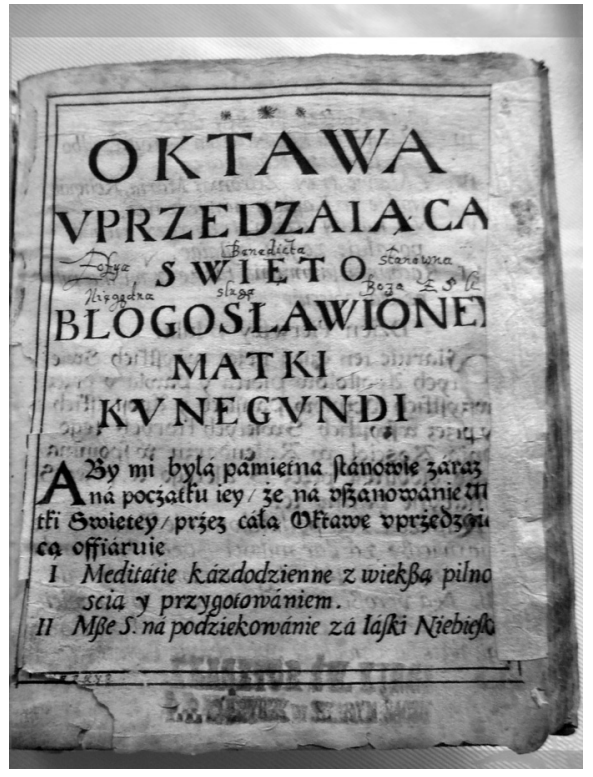

Fot. 10. Karta tytułowa: Oktawa vprzedzaiaca święto Błogosławioney Matki Kvnegvndi, Kraków XVII w., sygn. BK/he-1. Fot. Małgorzata Mirek. 


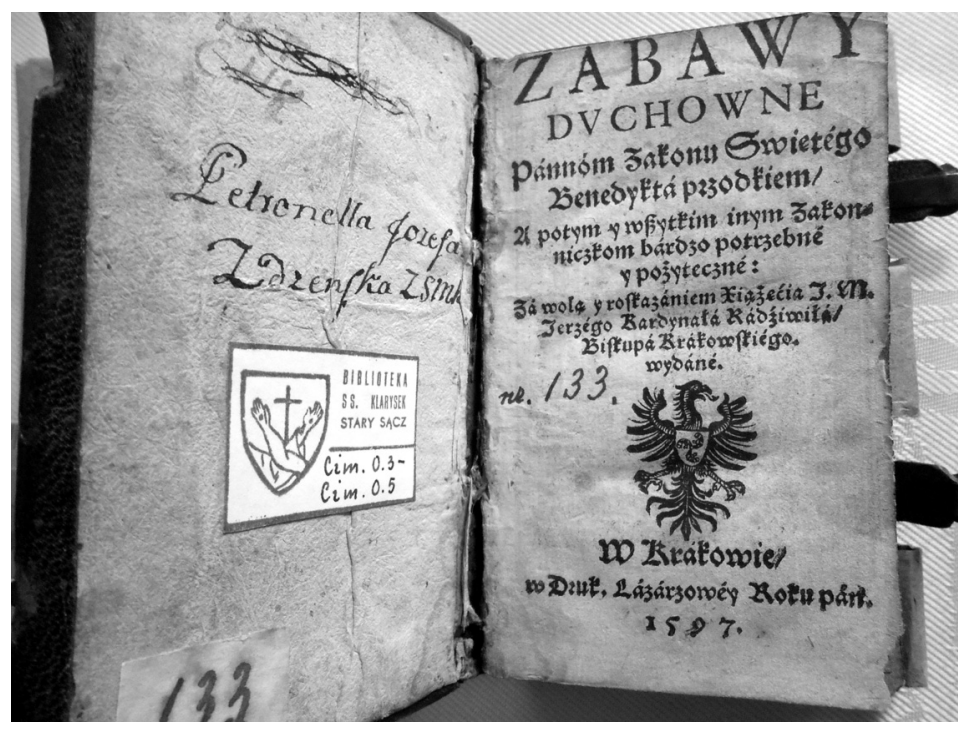

Fot. 11. Karta tytułowa: Zabawy dvchowne Pannom Zakonu Świętego Benedykta przodkiem a potym y wszystkim inym Zakonniczkom bardzo potrzebne y pożyteczne, Kraków 1597, sygn. Cim. 0.3.

Fot. Małgorzata Mirek.

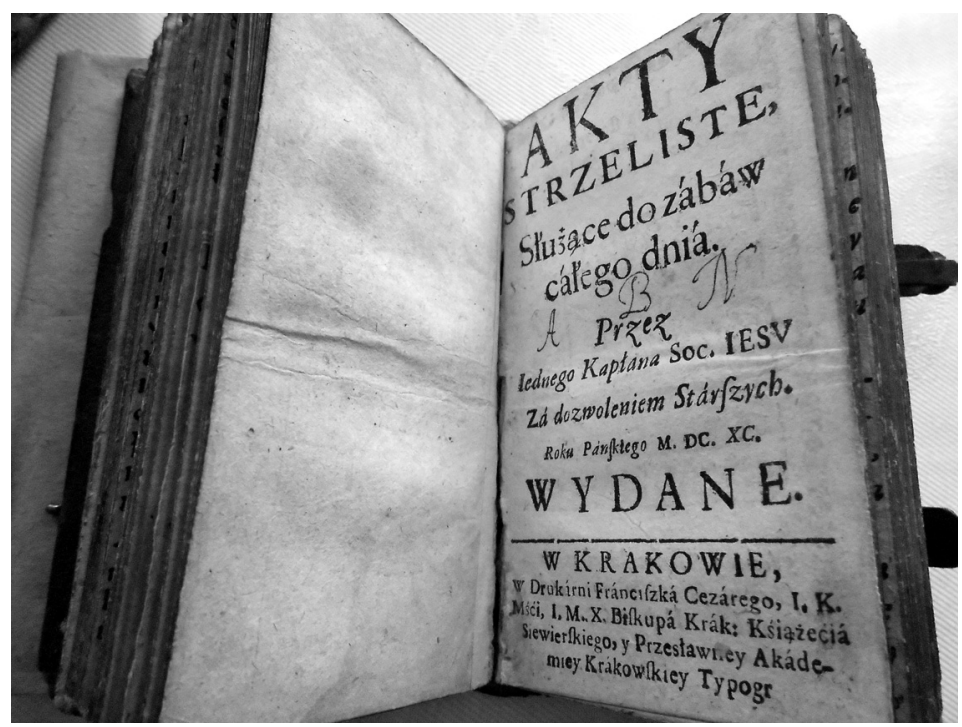

Fot. 12. Karta tytułowa: Akty strzeliste stużace do zabaw całego dnia, Kraków 1690, sygn. Cim. 0.5. Fot. Małgorzata Mirek. 